(C) 2013 Public Financial Publications, Inc.

\title{
The Opportunity Cost of Public Funds: Concepts and Issues
}

\author{
JÉRÔME MASSIANI AND GABRIELE PICCO
}

\begin{abstract}
This paper reviews the main conceptual issues regarding the notion of Opportunity Cost of Public Funds (OCPF) and its use in normative economics. Despite the importance of the mechanisms it illustrates, the OCPF still has received too marginal attention in public economics literature and is often handled with some definitional ambiguity. Our review indicates that the core of the notion lies in the deadweight loss and, to a minor extent, in administrative costs, while other aspects like crowding out are more controversial. Moreover, we argue that the financing mechanisms of the public expenditures should be considered for a proper analysis and quantification of OCPF and suggest that public expenditures are generally financed through the displacement of funds from alternative uses. We conclude with a review of available quantifications.
\end{abstract}

\section{INTRODUCTION}

The Opportunity Cost of Public Funds (OCPF) can be considered as a measure of the "real" cost of public funding. Typically, when the Public Sector finances expenditures through taxation, the situation of economic agents is affected and society as a whole suffers a loss of efficiency. In other words, raising one unit of public funds costs more than one to the society. As stated by Lebègue, the OCPF represents a

fictitious price to be assigned to every Euro of Public expenditure in the calculations, because of distortions and losses of efficiencies introduced by taxation in the economy (Lebègue et al. 2005, 66).

The notion of OCPF is usually present in two different fields of economics: fiscal policy, where it is used in the discussion about the optimal size of the budget and the split of the fiscal

Jérôme Massiani is Assistant Professor in Univerisità Cà Foscari di Venezia. He can be reached at j.massiani@unive.it.

Gabriele Picco was affiliated with Università degli studi di Trieste when he mostly contributed to this paper. 
burden across different forms of taxation; and project evaluation, where it provides the real cost of investments. OCPF is relevant in that it applies a social cost to transfers between the private and the public sector, which would otherwise be regarded as costless. Symmetrically, OCPF also applies to public revenues and increases the "value" of public incomes in the assessment of projects and policies. In Cost-Benefit Analysis, OCPF would typically increase the project costs; this could, in a number of situations, change the result (the sign) of an evaluation outcome. Although intrinsically necessary in any public policy appraisal, the notion of OCPF is often omitted in empirical economic analysis. It is rarely emphasized in Cost-Benefit guidelines or manuals and is frequently omitted in the practical implementation of Cost-Benefit Analysis. Illustrative of this situation is the recommendation formulated for the assessment of transport projects in Scotland. On the one hand, Transport Scotland (2009, section 12.7 "Headline indicators in STAG') recognizes the relevance of the notion, stating that:

The BCR [benefit-cost ratio] should also take account, in principle, of the distortionary impacts of general taxation on the economy. This principle (...) might imply a $30 \%$ uplift to expenditure costs. Applying the SOCEF criteria would mean that any projects or expenditure with a BCR of less than 1.3 would not be value for money.

However, on the other hand, it also gives license to omit it in practical application, since:

The current Green Book [Treasury Guidance] does not however require the SOCEF to be applied, so any expenditure with a BCR over one might be considered as worthwhile pursuing.

The problem of determining the actual cost of taxation started to receive some interest at the beginning of the 1970s, with special reference to French administration and in particular within the Commissariat Général du Plan. Since then, its use has gradually developed and the OCPF is now integrated into Cost-Benefit Analysis procedures in some countries (France for instance). Parallel to this interest for project evaluation, during the 1970s an analogous interest also emerged in the American literature, which has concentrated on the specific issue of the deadweight loss of taxation.

The main purpose of this paper is to shed light on the most relevant aspects of the OCPF, to discuss the most debated issues of the concept, and to provide some guidelines for practitioners. In a first step (A Multifaceted Notion Section), a definitional clarification is proposed; secondly (The Deadweight Loss Is the Core of OCPF Section), we concentrate on the problem of the deadweight loss of taxation; then (Administrative Costs, Including Corruption, Are Also a Cost of Public Funding Section), we consider the tax collection costs and the impact of corruption while The Crowding Out Measures the Effect of Taxation on Forgone Private Investments Section is devoted to the so-called "crowding out" effect. Funding Mechanisms: Increased Taxation, Debt, or Foregone Alternative Expenditures? Section discusses the question of how the mechanism of funding (additional taxes versus foregone alternative use of the budget) may influence the OCPF. Discussion and Conclusion Section summarizes the most relevant findings of this paper and draws up the conclusion. 


\section{A MULTIFACETED NOTION}

The definitions of OCPF found in literature are heterogeneous. American economists tend to concentrate mainly on the problem of the deadweight loss and their analyses consist in estimating the reduction in workers' surplus when wage taxation is modified. By contrast, European authors (especially the French ones) also consider other elements like administrative costs and corruption; nonetheless, most of their analyses are made in terms of more general concepts, as they often refer to "distortions" and "inefficiencies." Moreover, their approach is generally more theoretical than practical and only a few numerical estimations are provided. Additional to these main approaches that are mainly microeconomic, other approaches focus on macroeconomic effects, particularly the crowding out of private investments.

Table 1 presents a few approaches to defining the OCPF which could be considered as representative of the existing literature. The table suggests that we are dealing not with one welldefined concept, but with a constellation of concepts, whose naming varies from one author to another.

First, some authors use different expressions to talk about the same thing. In some situations, differences between distinct expressions are fairly tractable as they relate to well-established conventions of economic literature. For instance, some authors, especially in the American literature, opt for the expression Marginal Cost of Public Funds (MCPF) rather than OCPF. In practice, these two expressions are often used with reference to the same phenomena and could be considered interchangeable, with the only provision that MCPF makes explicit the marginal nature of incremental spending that is usually at stake when considering public expenditures. ${ }^{1}$

Second, apart from using different expressions to label the same things, there is a more critical issue in that the authors use the same expression to talk about different things. As it appears from Table 1, the different impacts that are included within the wording "opportunity cost of public funding" relate to:

1. Microeconomic effects on consumers. This consists of the reduction of consumer surplus occurring when the increase in taxation shifts upward the supply curve. Although less specific, the concept of "distortion" seems to refer to the same mechanisms. This latter concept is also sometimes referred to with other expressions like Distortions in economic agents' behavior which is sometimes inclusive of crowding out or Distortions and inefficiencies of the tax system which is admittedly loose.

1. However, Auriol and Blanc $(2007,15)$ suggest a somehow alternative distinction:

The opportunity cost of public funds is different from the marginal cost of public funds (i.e., the deadweight loss created by increasing marginally a specific tax). The marginal cost of public funds is a general equilibrium concept. It is relevant in the long run because it indicates the social cost (or benefit) of tax reform.

It seems that Auriol and Blanc do identify a kind of difference between the OCPF and the MCPF which takes into account the more general and comprehensive character of the former and the incremental and numerically rigorous nature of the latter. However, consistent with mainstream economic literature, we would be reluctant to generally accept the statement of the authors, as we find no reason to restrict the notion of marginal cost to general equilibrium approach (and opportunity cost to partial equilibrium). 
TABLE 1

Definitions of the OCPF and Similar Concepts in the Economic Literature

\begin{tabular}{|c|c|c|c|c|c|c|}
\hline \multirow[b]{3}{*}{ Expression } & \multirow[b]{3}{*}{ Refs. } & \multicolumn{5}{|c|}{ Rationale } \\
\hline & & \multicolumn{2}{|c|}{$\begin{array}{l}\text { Microeconomic } \\
\text { effects on } \\
\text { consumer }\end{array}$} & \multicolumn{2}{|c|}{$\begin{array}{l}\text { Costs related } \\
\text { to the public } \\
\text { administration }\end{array}$} & \multirow{2}{*}{$\begin{array}{c}\begin{array}{c}\text { Macroeconomic } \\
\text { effects }\end{array} \\
\begin{array}{c}\text { Crowding } \\
\text { out of private } \\
\text { investments }\end{array}\end{array}$} \\
\hline & & $\begin{array}{l}\text { "Distortions" } \\
\text { in agents' } \\
\text { behavior }\end{array}$ & $\begin{array}{l}\text { Deadweight } \\
\text { loss of } \\
\text { taxation }\end{array}$ & Corruption & $\begin{array}{c}\text { Tax } \\
\text { collection } \\
\text { costs }\end{array}$ & \\
\hline \multirow[t]{4}{*}{$\begin{array}{l}\text { Opportunity Cost of } \\
\text { Public Funds }\end{array}$} & Auriol and Blanc (2007) $)^{\mathrm{a}}$ & Yes & Yes & & & \\
\hline & Bernard $(1976)^{b}$ & Yes & & & Yes & \\
\hline & Butault $(2004)^{\mathrm{c}}$ & Yes & & & Yes & \\
\hline & Vaquin (1974) & & & & & Yes $^{\mathrm{s}}$ \\
\hline \multirow[t]{2}{*}{$\begin{array}{l}\text { Opportunity Cost of } \\
\text { Public Funds/ } \\
\text { Marginal Cost of } \\
\text { Public Funds }\end{array}$} & Lebègue et al. $(2005)^{\mathrm{d}}$ & Yes & & & No & \\
\hline & Marty et al. (2006) & Yes & & & & $\mathrm{Yes}^{\mathrm{t}}$ \\
\hline $\begin{array}{l}\text { Opportunity Cost of } \\
\text { Public Funds/Shadow } \\
\text { Price of Public Funds }\end{array}$ & Florio $(2002,2006)^{\mathrm{e}}$ & Yes & & Yes & & \\
\hline $\begin{array}{l}\text { (Marginal) Cost of } \\
\text { Public Funds }\end{array}$ & Bernard $(1976)^{f}$ & Yes & Yes & & No & \\
\hline \multirow[t]{4}{*}{$\begin{array}{l}\text { Marginal Cost of Public } \\
\text { Funds }\end{array}$} & $\begin{array}{l}\text { Browning and Liu } \\
\text { (1998) }\end{array}$ & Yes $^{\mathrm{m}}$ & & & & \\
\hline & $\begin{array}{l}\text { Dahlby and Ferede } \\
\text { (2011) }\end{array}$ & Yes $^{\mathrm{n}}$ & & & Yes $^{r}$ & \\
\hline & $\begin{array}{l}\text { Hashimzade and Myles } \\
(2009)^{\mathrm{g}}\end{array}$ & & Yes & & Yes & \\
\hline & Ruggeri (1999) & $\mathrm{Yes}^{\mathrm{o}}$ & Yes & & & \\
\hline \multirow{2}{*}{$\begin{array}{l}\text { Marginal Excess } \\
\text { Burden/Welfare Cost } \\
\text { of Taxation }\end{array}$} & $\begin{array}{l}\text { Ballard and Shove } \\
\qquad(1985)^{\mathrm{h}}\end{array}$ & Yes & & & & \\
\hline & Feldstein (1997) & $\mathrm{Yes}^{\mathrm{p}}$ & $\mathrm{Yes}^{\mathrm{q}}$ & & & \\
\hline $\begin{array}{l}\text { Marginal Social Cost of } \\
\text { Taxation (or of } \\
\text { Public Funds) }\end{array}$ & Spackman $(2007)^{\mathrm{i}}$ & Yes & & & Yes & Yes \\
\hline $\begin{array}{l}\text { Social Cost of Public } \\
\text { Funds }\end{array}$ & Laffont $(1999)^{\mathrm{j}}$ & & & Yes & & \\
\hline $\begin{array}{l}\text { Social Opportunity Cost } \\
\text { of Funds }\end{array}$ & Baumol $(1968)^{\mathrm{k}}$ & Yes & & & & Yes \\
\hline $\begin{array}{l}\text { Economic Opportunity } \\
\text { Cost of Public Funds }\end{array}$ & $\begin{array}{l}\text { Jenkins and Harberger } \\
\qquad(1998)^{1}\end{array}$ & & & & & Yes \\
\hline
\end{tabular}

${ }^{a}$ The opportunity cost of public funds is different from the Marginal Cost of Public Funds (i.e., the deadweight loss created by increasing marginally a specific tax). The Marginal Cost of Public Funds is a general equilibrium concept. It is relevant in the long run because it indicates the social cost (or benefit) of tax reform ... In developed economies [the opportunity cost of public funds], is mainly equal to the deadweight loss accrued to imperfect income taxation ... In developing countries, low income levels and difficulties in implementing effective taxation programs are strong constraints on the government's budget, which leads to higher values of [the opportunity cost of public funds]. 
b ... it could be assumed that the administration financing itself and the public expenditures financing entail specific costs. On the one side, a cost inherent to the functioning in general of the administrations ... On the other side, it is to be considered a cost of fiscal distortion which represents the losses in terms of efficiency due to the price distortions caused by tax collection ... This represents a psychological cost referred to an arbitrage between private and collective consumption, between a scale of preference left to the disposal of a certain income and that entrusted to the State or shifted to it. ${ }^{c}$ Public funds have an opportunity cost: the financing thanks to public funds needs to collect a tax. Now, the collection of a tax implies a cost for the society: it implies an administrative cost; it also induces some losses due to a reallocation of national resources engendered by the modification of tax-payers' decisions which creates distortions to the economy.

${ }^{\mathrm{d} O p p o r t u n i t y ~ c o s t ~ o f ~ p u b l i c ~ f u n d s, ~ a s ~ a ~ f i c t i t i o u s ~ p r i c e ~ t o ~ b e ~ a s s i g n e d ~ t o ~ e v e r y ~ E u r o ~ o f ~ P u b l i c ~ e x p e n d i t u r e ~ i n ~ t h e ~ c a l c u l a t i o n s, ~}$ because of distortions and losses of efficiencies introduced by taxation in the economy ... A first aspect often suggested to explain this cost— but that does not appear relevant — corresponds to tax collection: establish and collect the tax costs to the society ... However, this point is not to be overestimated ... So we can conclude that it is not appropriate to keep it into consideration, with special reference to the fact that it is essentially a fixed cost ... The real cost of taxation, its economic cost is that of distortions which it causes in private agents' behavior.

${ }^{\mathrm{e}}$ Public funds have a shadow price due to distortionary taxation. The tax-payer finances the grant, plus any rent extracted by agents because of rent-seeking and corruption, and because taxation is distortional, there is a shadow price for public funds. ${ }^{\mathrm{f}}$ The collection of financial resources through taxation is costly ... There is a first aspect, which is the collection cost. Establish and collect the tax costs ... We do not have ... to consider it, also because it is essentially a fixed cost ... The real cost of taxation, its economic cost is that of distortions which it causes. Economists have realized that the neutral tax collection which they imagined-lump sum transfers - only exists in the theory. Every concrete tax collection system creates distortions.

${ }^{\mathrm{g}}$ All implementable government tax instruments are distortionary and, as a consequence, impose deadweight losses upon the economy. These distortions are the inevitable cost of collecting the finance required to support public spending ... The cost of collecting revenue will depend upon the tax base that is chosen and the structure of rates that are levied. The Marginal Cost of Public Funds (MCF) is a measure of the cost of raising tax revenue from a particular tax instrument.

${ }^{\mathrm{h}}$ Estimates of Marginal Excess Burden (MEBs) stand in contrast to estimates of the welfare cost of taxes which are calculated by totally removing existing taxes and replacing them with equal yield lump sum taxes. Instead, an MBE estimate measures the incremental welfare costs of raising extra revenue from an already distorting tax.

${ }^{i}$ Spending on public investment is multiplied by a shadow price, relative to Euros of current expenditure or consumption benefit, to reflect its supposedly higher opportunity cost ... Valuation of this opportunity cost — the marginal social cost of taxation of public funds - involves many factors. One is the marginal administrative cost of tax collection. More complex are other impacts on consumer, employee and corporate behavior (including private investment). Also relevant are political perspectives, such as the ethical arguments against taxation; and its potentially beneficial impacts on distribution.

${ }^{\mathrm{j}}$ Inefficient Tax Systems ... to eliminate historical (often politically motivated) anomalies of the tax system ... transfers from the regulator are possible, but they entail a social cost of public funds. ... The lack of resources and human expertise for monitoring, auditing and enforcement is pervasive in developing countries ... But these shortcomings are usually underestimates, despite their dramatic implications for many areas of public policy. They are a major cause of the inefficient tax system..., they foster corruption.

${ }^{k}$ The government's use of resources deprives consumers of some goods ... The decision to devote resources to investment in a public project means, given the overall level of employment in the economy, that these resources will become unavailable for use by the private sector. And this transfer should be undertaken whenever a potential project available to the government offers social benefits greater than the loss sustained by removing these resources from the private sector. ${ }^{1}$ If people from their perspective have already allocated their funds between investment and consumption optimally, then if the government or the public sector is to put more resources into investment we should expect some displacement also of consumption ... if public sector projects are not undertaken then more resources will be available for allocation among private sector investment and consumption activities ... In every country capital resources are scarce; if the government expands faster, the growth of private sector over the long run will tend to be slower ... funds used in the public sector generally have an opportunity cost which is related to both postponed current consumption and forgone private investment. ${ }^{\mathrm{m}}$ The marginal cost of funds (MCF) ... identifies the magnitude of the marginal distortionary cost in raising revenue. ${ }^{\mathrm{n}}$ The Marginal Cost of Public Funds (MCF) is a measure of the loss incurred by a society in raising an additional dollar of tax revenue from a particular tax source ... Tax increases distort economic decisions and erode tax bases because of tax avoidance and tax evasion by taxpayers ... These tax wedges distort economic decisions, leading to an allocation of resources that, generally speaking, is less productive or beneficial to society as a whole. 
${ }^{\circ}$ When tax revenue is used to pay for the purchase of goods and services, resources are shifted from the private to the public sector and some private spending is replaced by public spending ... there is the possibility that the coercive nature of taxation may produce behavioral responses that affect society's welfare ... The measurement of the dead-weight loss can be applied to the total burden of a tax or to the tax system as a whole. It may also be confined to increases in the rate of taxation, for a given tax or for a variety of taxes individually or in combination ... If the tax increase raises the dead-weight loss of taxation by increasing distortions in the allocation of resources, it will cost society more than $\$ 1$ to transfer a dollar's worth of resources from the private to the public sector and the MCPF is greater than one ... the loss of output and utility produced by the tax-induced distortions of private agents' choices.

${ }^{\mathrm{p}}$ There are three types of behavioral effects that should be taken into account ... A higher marginal tax rate on income induces a substitution of untaxed fringe benefits and more pleasant working conditions for taxable cash income ... Even individuals who appear to have no discretion about the form of their compensation will be able to make such a substitution in practice, because the invisible hand of the market induces employers to offer more attractive forms of compensation ... The relevant distortion to labor supply is not only the effects of tax rates on participation rates and hours but also their effect on education, occupational choice, effort, location, and all of the other aspects of behavior that affect the short-run and the longrun productivity and income of the individual ... the relevant distortion is not just in labor supply broadly defined but also in the forms of compensation and in the demand for deductions and other ways of reducing taxable income.

${ }^{\mathrm{q}}$ The magnitude of that burden depends on the increases in tax rates required to raise incremental revenue and on the deadweight loss that results from higher tax rates ... it is the deadweight loss of resource misallocation that we economists think of as the true cost of raising taxes. Both components depend on the full range of behavioral responses of taxpayers to increases in tax rates.

${ }^{\mathrm{r}}$ Collecting taxes also involves large public administration costs and imposes compliance costs on the private sector.

${ }^{\mathrm{s}}$ Every public investment has the consequence to directly or indirectly transfer a certain amount of private investment and thus to equally reduce future consumption.

${ }^{t}$ The opportunity cost of public funds, that is, the impact of compulsory withdrawals and of debt on private investment and economic activity in general.

2. Some administrative costs in a broad meaning that refers to the tax collection costs and to the incidence of corruption.

3. Some macroeconomic effects that mainly rely, in a 1970s fashion, on the fact that private investment is displaced by public taxes or borrowing.

In the next sections of this paper, we concentrate in turn on each of these three components, and analyze how they should be taken into account when accounting for the full cost of public funding.

\section{THE DEADWEIGHT LOSS IS THE CORE OF OCPF}

As suggested by Table 1, the central element to be considered in OCPF's analysis is the deadweight cost of taxation.

\section{Theoretical Settings}

Deadweight loss represents the fact that, when the tax burden rises, a certain amount of mutually advantageous transactions are not taking place any more. All these units of goods which are sacrificed represent a reduction of consumer and producer surplus: this welfare loss does not consist of a direct monetary cost, but represents a form of inefficiency. 
As illustrated in Table 1, many economists present the deadweight loss as the only relevant mechanism in the OCPF's analysis. Under the simplifying assumptions that data on equilibrium price and quantity and the elasticity of demand and supply are available, the deadweight cost of a tax levied on one specific good can be calculated using Equation (1) as in Bishop (1968):

$$
\mathrm{DL}=\frac{1}{2} \frac{P Q}{\left(1 / \varepsilon_{s}\right)+\left(1 / \varepsilon_{d}\right)} t^{2}
$$

with DL, deadweight loss of taxation; $P$ and $Q$, respectively, price and quantity of the good/ service before tax; $\varepsilon_{\mathrm{d}}$ and $\varepsilon_{\mathrm{s}}$, respectively, the compensated price elasticity of demand and supply for the good; $t$, tax rate on the good.

In Equation (1), the deadweight loss varies with the square of the tax rate. This means that the level of inefficiency generated by additional taxation is proportionately more for high tax rates than for the low ones and generally higher if the original tax rate is high.

Based on this simple setting, some more detailed issues should be considered. First, a distinction is sometimes made in literature between differential and balanced budget analysis (Ruggeri 1999). In a "differential" analysis, tax revenue and the expenditure level are kept constant in order to assess what are the effects of a particular tax, compared to those of a lump sum tax providing identical revenue. Instead, in a "balanced budget" analysis, we measure the social costs of collecting one more unit of public funds: that is why both tax revenue and the level of expenditure change. As will be illustrated below, there is some evidence that the welfare loss analyzed through differential analysis is larger than through balanced budget analysis (Browning 1987; Stuart 1984).

Second, the magnitude of deadweight loss should take into account market imperfections. For instance, in the presence of monopolistic positions, the effect of marginal taxation should be reformulated: starting from an initial situation where the monopolist can set the prices above the marginal cost of production (i.e., it enjoys market power), Rosen (2005) demonstrates that taxing such a good will generally entail a loss of surplus smaller than in the competitive situation, since the deadweight loss of taxation will partly compensate with the erosion in the market power of the monopolist (i.e., the deadweight loss of monopoly). The entity of that compensation depends on demand elasticity and, as an extreme case, it should even be possible for the OCPF to be smaller than 1. Considering that monopolistic markets are not infrequent in modern economies, one should certainly be careful in generalizing results from pure competition analysis.

Third, consideration is sometimes made of the use of tax incomes. This relates to (1) the fact that the welfare loss should be balanced with benefits of Pigouvian taxes and to (2) the redistribution of revenues. This attention on the use of tax revenues may however be highly misleading.

Considering (1), Pigouvian taxes: if the taxation is exactly offsetting an externality (simply suppose the consumption of one unit of a good generates a $X \$$ /unit externality and a tax of $X$ $\$ /$ unit is imposed), then taxation is not creating a deadweight loss but is reducing the loss due to the externality. However, in many cases, the level of taxation may exceed the magnitude of the externality. In these circumstances, it is relevant to take into account a deadweight loss, as far as 
the taxation exceeds the externality. In other words, the existence of the externality means that taxation will lead to distortion insofar as it exceeds the magnitude of externalities. This statement has political implications (this means that the opportunity cost cannot be invoked a priori against taxation in all circumstances) as well as practical implications (in computation only the fraction of tax increase that exceeds externality should be associated with a deadweight cost). ${ }^{2}$

Considering (2), the impact of taxation on distribution, it is questionable whether the OCPF is an appropriate tool, and whether the effects of deadweight offset any desirable redistributive effects.

For this reason, of the three issues that were quoted, it is reasonable that only the first two ones really raise questions of practical relevance, that is, differential versus balanced budget analysis and market imperfections such as monopoly.

\section{Estimation Issues}

Having described the theoretical setting of the deadweight loss we will discuss the estimates of the magnitude of this effect.

The most relevant works devoted to the empirical estimation of the deadweight loss of taxation (Browning 1976, 1987, Feldstein 1997, Stuart 1984) concentrate on the impact of taxation on the labor market of western countries. These authors generally focus on two key parameters: the marginal rate of taxation (as in Equation 1) and the labor supply elasticity. To some extent, the latter substitutes the price elasticity, which appears in Equation (1), when we want to calculate surplus loss within the labor market.

Browning (1976) performed a differential analysis of partial equilibrium, with reference to an increase in wage taxes in the United States. One of his assumptions was that the whole tax revenue was distributed through direct transfers to the poorest citizens; he considered both the compensated supply elasticity on work and the marginal rate of taxation. Varying the values of these parameters, his estimates of the OCPF fell within a range of $1.09-1.16,{ }^{3}$ including a 0.07 coefficient for the administrative costs. However, in Browning (1987), using different values of the supply elasticity and of the marginal rate of taxation, the OCPF is estimated as follows: within 1.18-1.47 for differential analysis and in a range of 1.15-1.32 for the balanced budget. The first of each pair of values is associated with proportional taxation while the second refers to progressive taxation, thus indicating that the latter is more distortionary than the former.

Also Stuart (1984) analyzed income taxation with reference to the same variables, but considering two sectors, one with taxes and the other one without taxation. By contrast, he did not make the specific assumption that the tax revenue is to be redistributed to the neediest population. His values felt within the ranges of 1.21-1.57 and 1.07-1.43, respectively for the differential and the balanced budget analysis.

2. We are aware that this statement may become controversial in a general equilibrium analysis.

3. OCFP is expressed as a ratio. 1.16 means that each euro spent has to be counted for 1.16 euro. 
Feldstein (1997) made a relevant balanced budget analysis in a general equilibrium setting with reference to income taxation in the United States. His approach explicitly rejects Keynesian demand effects, and concentrates on three other crucial effects of taxation. First, increasing wage taxation may entail a reduction in the labor supply and, in the long term, also in the capital stock. At this stage, not only labor force participation and working hours should be considered, but also a broader range of behaviors like: the choice of occupation, the accumulation of human capital, working conditions and the level of personal engagement of workers. Second, both workers and enterprises are encouraged to search for alternative, tax-free wage systems (i.e., bonuses, taxfree rewards and indirect benefits), in order to minimize their fiscal burden. Third, the higher is work taxation, the more favored is the consumption of deductible and deducible goods. Taking all these effects into consideration, the author obtains an OCPF of 2.65 for the 1985-1988 wage tax system of the United States. Feldstein (1997) introduces novel elements to assess some crucial issues, such as the fact that different taxation instruments can be associated with different levels of distortion. However, despite these advances, the author acknowledges and encourages more studies on the subject.

A very comprehensive approach is then proposed by Snow and Warren (1996), who derived a formula to calculate the OCPF, without a priori restrictions on individual preferences and on available technology. Their formula, with some modifications, is valid for both differential and balanced budget analysis of taxation on the labor market. They considered both compensated and uncompensated supply elasticity, the marginal rate of taxation, the extent of tax exemptions and, with reference to the destination of taxation, the level of provision of the public goods as well as the extent of the direct transfers to poorer citizens. They concluded that, on the whole, the OCPF is determined by the result of three different effects: the first one is the income effect due to taxation, followed by the substitution effect (always due to taxation). The third one is the effect on the worker/tax-payer from (positive) expenditure outcomes and from transfers financed by tax revenues. However, in this way, Snow and Warren made the same debatable choice as Browning as they decided to include the benefits of public expenditures in the definition of the OCPF: it is uncontroversial that budget expenditure generates benefits, but it is, again, in our view, confusing to include such effects in the notion of OCPF. Another issue is that with Snow and Warren's formula, no OCPF is associated with a compensated supply elasticity of zero. Nonetheless, and more importantly, with lump sum taxes, the OCPF could be less than one, if only the absolute value of positive outcomes on the tax-payer were greater than the income effect due to taxation.

Although these works do represent useful contributions to the analysis of the OCPF, one may find a limitation in that they often relate to the taxation of labor market, and may not be easily transferable in contexts where the source of funding is not related to labor market or, a more frequent situation, cannot be identified. Moreover, these authors (with some exceptions, like Snow and Warren 1996) considered the deadweight loss as the only relevant aspect of the cost of public funds, thus stating that lump sum taxes would be associated with no OCPF. However, the OCPF often refers to other effects as we will illustrate in the rest of this paper. 


\section{ADMINISTRATIVE COSTS, INCLUDING CORRUPTION, ARE ALSO A COST OF PUBLIC FUNDING}

In addition to the deadweight loss, the cost of government expenditures should also include what we identify as "administrative costs."

\section{Rationales for Including Administrative Costs}

Administrative costs represent all the costs associated with tax collection and public expenditure management as well as the private costs that agents have to bear in order to comply with fiscal obligations (bookkeeping for instance). Administrative costs are obviously only a component of the OCPF: none of the authors who explicitly mentioned them (Bernard 1976; Butault 2004) proposed to refer to the administrative costs as the only relevant element of the OCPF. Bernard (1976) states that these costs have to be considered as:

a cost pertaining to the functioning, in general, of the administrations; this kind of cost has its equivalent in the private sector, that is the transactional costs; but some components have with no doubt a greater relevance in the public sector than in the private. (...) the same happens for the costs of programs implementation and for the control of the undertaken decisions. (Bernard 1976, 73-74)

According to this author, a value representing the larger administrative costs of the public sector compared to the private sector should therefore be included in the OCPF. However, this issue is controversial. Lebègue et al. (2005) compared tax collection costs (estimated in terms of expenditures from the fiscal administration authorities) with collection, management and transactional costs of the private companies and found that they were of limited magnitude.

One of the most important arguments when considering the administrative costs of taxation relates to the relevance of fixed versus variable administrative costs. An attractive solution would be to consider that additional administrative costs will be negligible when considering an increase of the tax rate, and may be nonnegligible when the introduction of a new taxation is considered. However the specific source of public funding is often not identified (as will be illustrated more in details in the last section of this paper).

\section{Corruption Costs Are Also Part of the OCPF}

Besides the administrative costs which we have just discussed, corruption can also be included in the OCPF's analysis. Considering corruption, the reference to the administrative costs may seem improper; however, in some situations, corruption reduces the amount of public funds available for spending in a way very similar to administrative costs. In such situations, corruption can mean that a fraction of public funds "disappears" after they are collected and before they can be employed. In some other situations, corruption relates not to the disappearance of some funds but 
to the misuse of these funds, which can translate into increased costs of certain outputs, or allocation of spending to projects that provide only limited social benefits. When corruption operates in these latest forms, the issue of whether it should be included in the opportunity cost deserves careful investigation. Actually, if the cost data used for Cost-Benefit Analysis are realistic, they will reflect the cost increase due to corruption. Similarly, if the benefits of the project are estimated correctly, then any misallocation of the resources will be taken into account in the (limited) net benefits of the project. In these two situations, the inclusion of corruption in the opportunity costs of public funding would result in double counting.

Despite its potential impact on the use of public funds, corruption is often disregarded in the OCPF's analysis, especially in the most recent ones or in those which concentrate on western countries. However, even in some developed countries, the existence of corruption cannot be omitted from economic analysis as long as it is part of the real economy. ${ }^{4}$ As far as some developing countries are concerned, available analyses (Laffont 1999) indicate that corruption can become the most relevant element in the OCPF.

\section{Empirical Estimation of The Administrative Costs and Corruption}

Very few estimates are currently available for administrative costs or corruption, since the phenomena are often peripheral in the literature on OCPF. As we have already mentioned above, Browning (1976) proposed an opportunity cost of 1.07 to reflect the administrative costs related to labor taxation, but no information is provided by the author on the methods adopted for estimation. Bernard (2004) stated that, in developed countries, administrative costs account for 1.5 percent of total collected funds, whereas in France they would even reach 3 percent: although this value may be consistent with data on tax recovery administrative costs in the country, especially with reference to early 2000 s, the author provides only limited information on how these figures were obtained and on why they differ so much from one estimate to the other.

As far as corruption is concerned, it is fair to say that available figures are often anecdotal. Providing more robust and consolidated estimates on how much corruption can impact the cost of public fund would be beneficial to the debate about costs of public funding.

\section{THE CROWDING OUT MEASURES THE EFFECT OF TAXATION ON FORGONE PRIVATE INVESTMENTS}

Another effect which is often considered as part of the OCPF is the so-called "crowding out." Through this expression, the economic literature refers to the effects of public spending, either financed through taxation or public debt, on private investment. This effect is not very much present in the recent literature (with a few exception: Jenkins and Harberger 1998), and one could

4. Only few months ago, with reference to year 2009, the Italian Court of Accounts reported that corruption was still extraordinarily widespread in the country, particularly during the call for tenders procedures and the processes of public expenditure financing (with special regard to the healthcare system; Turno 2010,6) 
consider that it corresponds to a macroeconomic setting that is somehow outdated and refers to limited international mobility of capital.

Most of the literature on crowding out effect refers to public borrowing. Issuing public debt means that Government bonds placed on the market raise the demand for loan funds and, as a consequence, the equilibrium interest rate. Thus, loans would become more expensive for private investors, leading to lower investment.

Crowding out effect also applies to situations where public expenditures are financed through taxation. In this situation, it is suggested that taxes paid by household will reduce present consumption and savings (or future consumption). As a consequence, reduction in consumption will decrease the profitability of private investments, while fewer savings will result in higher equilibrium interest rate.

Jenkins and Harberger (1998, chapter 12) observe:

If public sector projects are not undertaken, then more resources will be available for allocation among private sector investment and consumption activities. Seldom, if ever, can the government isolate its investment and current expenditure activities from having an impact on their private sector counterparts. In every country capital resources are scarce; if the government expands faster, the growth of the private sector over the long run will tend to be slower.

This means that the reduced investments in the present due to the crowding out will imply fewer consumption possibilities for the future. On this issue, Vaquin states

It is then intuitive to define the Opportunity Cost of Public Funds as the present value of the future consumption which is given up for one [Euro ${ }^{5}$ ] of public investment undertaken in the present. (Vaquin 1974, 858-859)

As it appears, there is a fundamental difference between the crowding out effects and other approaches of opportunity costs, in that the former explicitly takes into account the macroeconomic effect of public spending. This motivates three reflections.

First, crowding out has lost great part of its relevance in modern economies. Nowadays the capital market is largely internationalized which reduces the effect of public borrowing on equilibrium interest rate. Although there are still some links between high level of public spending and high interest rates, they relate mainly to the risk of default of a given country, and not to the crowding out of private investment.

Second, there is a need for consistency in the integration of macroeconomic linkages in Cost-Benefit Analysis. Taking into account effects of extra taxation on savings and consumption is sound, but, to be consistent, the effect of extra public spending (on consumption and savings) should also be taken into account. However in the literature on the

5. Franc in the original text. 
OCPF the effect of the extra spending is often not clearly distinguished from the effect of extra taxation.

The key question about crowding out is not to know how much it counts but whether it should be taken into account at all. Probably the effect on financial markets can be omitted consistently with the general openness of capital markets in modern economies. The other macroeconomic linkages are more relevant but it is legitimate to ask whether they should be included in the OCPF. Most probably, these effects pertain to the realm of economic impact analysis and, although it is fully legitimate to take them into account in the evaluation of public spending, they ought to be isolated from the concept of opportunity cost of public funding. Generally, the actual relevance of the crowding out in the OCPF's analysis has to be carefully evaluated.

\section{FUNDING MECHANISMS: INCREASED TAXATION, DEBT, OR FOREGONE ALTERNATIVE EXPENDITURES?}

As is apparent from the previous sections, much of the reasoning that can be made about the impact of public expenditures considers different sources of taxation (income, corporate, payroll, sales taxes for instance). But, in addition to this question, another fundamental one, to our view, relates not to the source (which tax revenue is used to finance a given expenditure) but rather to the mechanisms of funding (whether the spending is financed through extra taxation, debt or foregone alternative use of the budget). In many situations, the exact source of funding is unknown (and sometimes undefined), while one may still have some knowledge about the funding mechanisms which he or she may want to use, as illustrated below, for his analysis. This issue raises a number of questions that usually are only marginally considered in the discussion among economists. Reasons for such limited attention can partly be found in the fact that, under the assumption of a fully informed, welfare maximizing public decision maker (and under the assumption that the voters would support such a decision maker), the social cost of public expenditure would equate among all different types of funding (all different taxes and debt), and the decision maker would additionally equate the marginal utility of public expenditures (per \$ spent) and the marginal welfare cost of taxation (otherwise, he would not be welfare maximizing). This simplified and hypothetical situation is depicted on Figure 1. If it were so, the question of the financing sources or mechanisms would be irrelevant, and the calculation could be carried out with no consideration of this issue.

In practice, of course, public decision makers are not fully informed welfare maximizers. It is therefore useful to consider how the (lack of) information about sources or mechanisms of funding should be taken into account when assessing public expenditures. Several considerations need here to be made.

First, and it is fairly uncontroversial, the source or mechanisms of funding are sometimes unidentifiable or even undefined. This is more true considering the source rather than the mechanism of funding. Regarding the source of financing, it is, in many circumstances, not only 
FIGURE 1

A Welfare Maximizing Public Decision Maker Would Equate Marginal Costs and Marginal Benefits of Taxation (Simplified Representation)

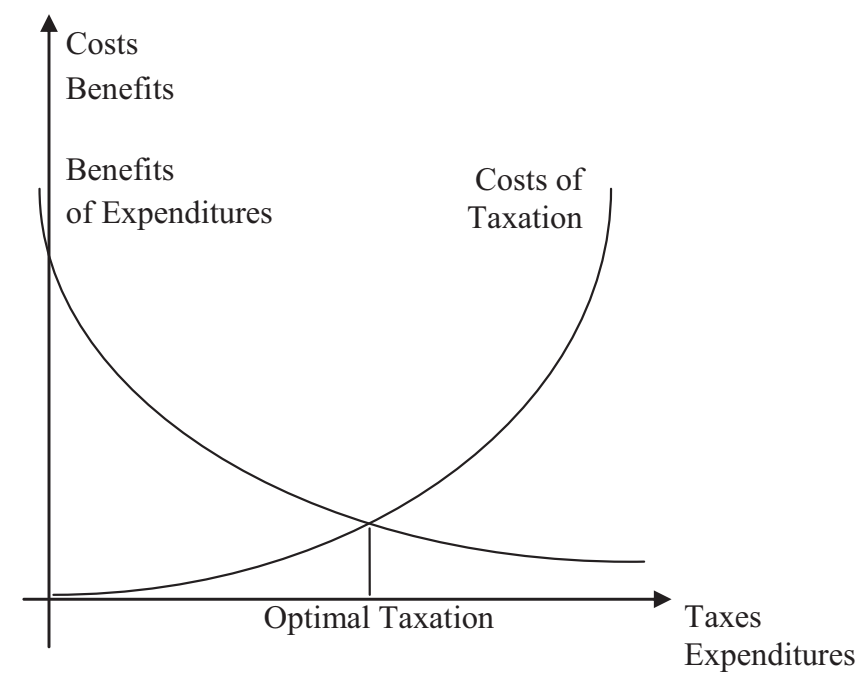

impossible to identify the source of financing, but it is also conceptually erroneous. This relates to the general situation where funds are not earmarked. This can be due to national budgeting practice or to rules set by the Constitution or constitutional law, when these latter indicate that all State revenues are placed in a single budget with no distinction of their provenience (see for instance the concept of "universalité budgétaire" (universality of the budget) that is applied to national budgeting in France based on ordonnance January 2, 1959). When no limitations are made de juris, there is often a de facto budget unity. In all these circumstances, it is wrong to consider that a given expenditure can have a given source of financing. This holds for the question about the funding source, but what about the funding mechanism? In contrast to funding sources, there will always be a funding mechanism since the expenditure is necessarily the outcome of some budgetary process (although not always a strictly deterministic or mechanistic one) and money will, in all occurrences, be obtained through some mechanism. The question is whether sufficient knowledge is available about these mechanisms to be used by economists even when they lack precise information about a given source of financing. Before to answer this question we need to make some other preliminary considerations.

A second consideration is that the set of possible financing mechanisms is incomplete if it only relies on increased taxation and debt and does not consider the shift of public funds from other expenditures. ${ }^{6}$ This issue is obviously different from what the "differential taxation" approach performs, which investigates how the shift from one type of tax to another one impacts economic efficiency. Thus the cost of public funding may not be, in many circumstances, the cost of increased taxation or increased debt but the opportunity cost of foregone benefits of other 6. We will leave aside monetary creation that is strictly controlled in most of contemporary economies. 
expenditures. While this may seem obvious, we find that this enlarged conception contradicts many implicit statements about public expenditures. Most of the literature about opportunity costs of public funding refers to "increasing public budget by one dollar," "increasing taxes," "increasing the size of the government" (we do not pinpoint here to specific texts, but browsing the reference of this paper is sufficiently illustrative of our point). Lastly, this omission of alternative use of public funds is all the most contradictory with the use of the term "opportunity cost" where "opportunity" literally places the emphasis on foregone alternative uses.

Then the challenge faced by economists is to know whether it is possible, when the source of funding is unidentified, to use some information about funding mechanisms in order to properly account for the opportunity cost of public funding. Or should the economist just rely on the simplifying assumption of equal marginal cost of taxation and equal benefit of public expenditures? The challenge is both theoretical and practical.

From a theoretical point of view, it appears often reasonable to assume that a project is actually financed through the displacement of other expenditures rather than through extra taxes. The reasons are that if any "new" expenditure were financed through an increase in taxation (respectively debt) then the public sector budget would increase its size at a rate that would not be compatible with any observed long-term trend in public expenditure among modern economies. Thus, unless a specific source of financing can be identified, it is reasonable to propose a calculation process that takes into account the opportunity cost represented by the foregone benefits of other expenditures. ${ }^{7}$

How can this theoretical solution be used in practice? In some cases, a solution is possible. We refer to situations where a lot of information is available about alternative expenditures. For instance, road projects in the United Kingdom systematically undergo a Cost-Benefit Analysis by the relevant transport authority. Then, if one classifies the different projects based on the benefit/cost ratio (where cost is solely defined as the public expenditures) and looks at the last financed project in this ranking, one obtains a valuation of the cost of foregone use of public funding. We however acknowledge that in many circumstances such a calculation is not possible. In this case, we may be disappointed to conclude that the economists may not have a better solution than relying on the (debatable) assumption that the policy maker equates MCPF and marginal utility of public expenditures.

\section{DISCUSSION AND CONCLUSION}

In this paper, we have presented an extensive panorama of the multifaceted concept of OCPF.

7. Theoretically, these opportunity costs can be based on the Lagrange multiplier of the budgetary constraint, as in Auriol and Blanc (2007). As a matter of fact, these authors explicitly underline that, since each government is confronted to limited resources, once a certain amount of public funds is invested in a specific project, less money is then available for other initiatives, though beneficial, which must be postponed or abandoned. 
Our analysis suggests, first, that a definitional clarification is necessary when this concept is used. We find that the same expression is indeed used to represent at least three phenomena: microeconomic deadweight loss due to taxation, administrative costs (and corruption), and the crowding out of private investment. Although all these different elements have, at different degrees, a scientific basis they should probably be assigned to different conceptual tools. Probably, the dominating use of OCPF in the meaning of deadweight loss provides sufficient indication for the practitioners to adhere to this terminology (although it does not strictly represent an opportunity cost). As far as administrative costs are concerned, it is best to consider them as a part of a larger category of transaction costs associated with public expenditure. Finally, considering crowding out effects, we find a dominating definition of such effects that refers to capital markets. We acknowledge that they may be of limited relevance in an open financial economy. A more comprehensive use of "crowding out" refers to other macroeconomics linkages. In this setting, apart from the necessity of consistency in taking into account only net macroeconomic consequences, these effects probably deserve to be dealt with explicitly and not placed within an inclusive (and arguably loose) concept of Opportunity cost.

TABLE 2

Estimates of the Opportunity Costs of Public Funds

\begin{tabular}{lcl}
\hline Country & Estimation & \multicolumn{1}{c}{ Source } \\
\hline Australia & 1.25 & \\
Canada & $1.2-1.3$ & Ruggeri (1999) \\
Philippines & 2.48 & Jones, Tandon, Vogelsang (1990) \\
France & 1.3 and 1.5 & Commissariat Général du Plan (1973 and 1985) \\
& $1.1-1.4$ & Applying Snow and Warren's formula (1996) \\
& $1.2-1.3$ & Bernard (1976) \\
& 1.12 & Bernard and Vieille (2003) \\
& $1.13-1.3$ & Lebègue et al. (2005) \\
& $1.05-1.2$ & Quinet (2006) quoting literature \\
& 1.3 & Auriol and Blanc (2007) \\
Japan & 1.03 & applying Snow and Warren's formula (1996) \\
Malaysia & 1.20 & Bernard and Vieille (2003) \\
Western countries & $1-1.5$ & Jones, Tandon, Vogelsang (1990) \\
& $1.3-1.5$ & Browning (1987) \\
United Kingdom & 1.3 & Laffont (1999) \\
& 1.3 & Florio (2002) \\
Russia & 1.23 & \\
Thailand & $1.19-1.54$ & Bernard and Vieille (2003) \\
USA & $1.17-1.56$ & Jones, Tandon, Vogelsang (1990) \\
& 1.02 & Ballard (1990) \\
\hline
\end{tabular}


Second, we propose to the practitioners a survey of the different values found in literature (Table 2). Based on the elements presented in this paper, it appears that a reasonable provisional OCPF, corresponding to deadweight loss, can be proposed in the range of $0.2-0.3$ for western countries. This assumes that every euro used by public authorities has a welfare cost of 1.20-1.30 euro. We recognize however that this indication cannot be considered as robust, and that it should be adapted, when relevant information on the specific type of taxation considered is available (Table 3).

Additional to that deadweight effect, additional transaction costs linked to tax collection can be added, considering the specific situation of a given country, but greater clarity would be achieved if they were labeled for what they are and not included in a too comprehensive notion of deadweight loss.

Furthermore, this paper analyzed how information on the source or the mechanism of funding could be relevant for a proper use of the OCPF. While the exact source of public funding is usually not available to the analyst, it is generally reasonable, in absence of other data, to assume that the mechanisms of public funding is the eviction of alternative uses of the public budget. This conjecture can be helpful when considering a project in sector where investments are systematically submitted to evaluation. In this case, the opportunity cost of funding can be measured by the ratio of benefits divided by the (appropriately defined) cost of the first nonfinanced project.

Eventually, we reckon it is interesting to suggest an additional area of research for OPCF, the one relating to the ongoing changes in the context of public financing. This relates in particular to the development of public-private partnerships (PPP). While the most trivial implication of PPP's would be to reduce the public cost of projects, as only the fraction of finance assigned to

TABLE 3

Estimates of the Opportunity Costs of Public Funds Associated With a Given Tax Source

\begin{tabular}{lccl}
\hline Country & Tax instrument & Estimation & \multicolumn{1}{c}{ Source } \\
\hline $\begin{array}{l}\text { Bangladesh, Cameroon } \\
\text { and Indonesia }\end{array}$ & Trade, consumption & $0.5-2.2$ & $\begin{array}{l}\text { Devarajan, Suthiwart-Narueput, and } \\
\text { Thierfelder (2001) }\end{array}$ \\
Canada & Income & $1.13-1.18$ & $\begin{array}{l}\text { Ruggeri (1999) } \\
\text { India }\end{array}$ \\
& Excise & $1.66-2.15$ & Ahmad and Stern (1987) \\
& Consumption & $1.59-2.12$ & \\
New Zealand & Import & $1.54-2.17$ & \\
Thailand & Income & 1.18 & Diewert and Lawrence (1994) \\
USA & Consumption & 1.065 & Chandoevwit and Dahlby (2007) \\
& Income & $1.09-1.16$ & Browning (1976) \\
& Income & $1.07-1.57$ & Stuart (1984) \\
& Income & $1.32-1.47$ & Browning (1987) \\
& Income & $1.08-1.14$ & Ahmed and Croushore (1992) \\
& Income & 2 or more & Feldstein (1997) \\
& & & With reference to years 1985-1988 \\
\hline
\end{tabular}


public funding would entail an opportunity cost (for a more complete discussion see Marty and Voisin 2007), it is likely that PPP's will have other implications, for instance in terms of transactional costs and in cost-quality prioritization, as pointed out by Trosa (2007). These questions however exceed the scope of the present paper and we can only invite for future research on this topic.

\section{REFERENCES}

Ahmad, E. and N. Stern. editors. 1987. The Theory of Taxation for Developing Countries. World Bank Research Publication, Oxford University Press.

Ahmed, S. and D. Croushore. 1992. "The Marginal Cost of Funds with Nonseparable Public Spending," Papers 9-92-7, Pennsylvania State - Department of Economics.

Auriol, Emmanuelle and Aymeric Blanc. 2007. "Public Private Partnership in Water and Electricity in Africa." Working Paper 38: 15-22. Agence Française de Développement. Paris.

Ballard, Charles L. 1990. "Marginal Welfare Cost Calculations-Differential Analyses vs. Balanced-Budget Analyses." Journal of Public Economics. 41: 263-276.

Ballard, Charles L. and John B. Shove. 1985. "General Equilibrium Computations of the Marginal Welfare Costs of Taxes in the United States." The American Economic Review. 75 (1): 128-138.

Baumol, William J. 1968. "On the Social Rate of Discount.” The American Economic Review. 58: 788-802. Bernard, Alain. 2004. Repenser le calcul économique public. Paris: Ministry of Equipment.

Bernard, Alain L. and Marc Vieille. 2003. "Measuring the Welfare Cost of Climate Change Policies: A Comparative Assessment based on the Computable General Equilibrium Model GEMINI-E3." Environmental Modeling \& Assessment. 8 (3): 199-217.

Bernard, Alexis. 1976. "Il Costo di Opportunità dei Fondi Pubblici." Problemi di Amministrazione Pubblica. I (3): 61-95.

Bishop, Robert L. 1968. "The Effects of Specific and Ad Valorem Taxes." Quarterly Journal of Economics. 82 (2): 198-218.

Browning, Edgar K. 1976. “The Marginal Cost of Public Funds.” Journal of Political Economy. 84: 283-298. 1987. "On the Marginal Welfare Cost of Taxation." American Economic Review. 77: 11-23.

Browning, Edgar K. and Liqun Liu. 1998. "The Optimal Supply of Public Goods and the Distortionary Cost of Taxation: Comment.” National Tax Journal. 51 (1): 103-116.

Butault, Jean-Pierre. 2004. Les Soutiens à l'Agriculture-Théorie, histoire, mesure. Paris: INRA.

Commissariat Général au Plan (CGP). 1973. Calcul économique et Planification - Rapport du Groupe de Travail "Taux d'actualisation et choix des investissements", Documentation française, Paris 1973.

Commissariat général du Plan. 1985. Recommandations sur les règles du calcul économique pour le IXe Plan, note ronéotée, Henri GUILLAUME, commissaire au Plan. (Octobre 1985).

Chandoevwit, Worawan and Bev Dahlby. 2007. "The Marginal Cost of Public Funds for Excise Taxes in Thailand," Taxation eJournal of Tax Research, ATAX, University of New South Wales.

Dahlby, Bev and Ergete Ferede. 2011. "What Does it Cost Society to Raise a Dollar of Tax Revenue? The Marginal Cost of Public Funds." C.D. Howe Institute Commentary. 324.

Devarajan, Shantayanan, Karen Thierfelder, and Sethaput Suthiwart-Narueput. 2001. "The Marginal of Public Funds in Developing Countries." In Policy Evaluations with Computable General Equilibrium Models, edited by A. Fossati, and W. Wiegard Wiegard. London: Routledge. pp. 39-55.

Diewert, W. E. and D. A. Lawrence. 1994. The Marginal Costs of Taxation in New Zealand. Canberra: Swan Consultants.

Feldstein, Martin. 1997. “How Big Should Government Be?” National Tax Journal. 50 (2): 197-213. 
Florio, Massimo. 2002. "A State without Ownership: The Welfare Impact of British Privatisations 19791997”, Working Paper no. 24/2002, Dipartimento di Economia Politica e Aziendale at Università degli Studi di Milano, Milano 12/2002.

Florio, Massimo. 2006. "Multi-Government Cost-Benefit Analysis: Shadow Prices and Incentives", Working Paper no. 37/2006, Dipartimento di Scienze Economiche, Aziendali e Statistiche at Università degli Studi di Milano, Milano 11/2006.

Hashimzade, Nigar and Gareth Myles. 2009. "Cost-Benefit Analysis and the Marginal Cost of Public Funds." Departimental Working Paper, 29. Department of Economics, Management and Quantitative Methods at Università degli Studi di Milano.

Jenkins, Glenn P. and Arnold C. Harberger. 1998. Cost Benefit Analysis of Investment Decisions, chapt. 12. Cambridge: Harvard Institute for International Development. 1-27.

Jones, Leroy P., Pankaj Tandon, and Ingo Vogelsang. 1990. Selling Public Enterprises: A Cost/Benefit Methodology, Volume 1, Edition 1. MIT Press Books, The MIT Press. Number 0262600625, October.

Laffont, Jean-Jacques. 1999. "Competition, Information and Development." In Annual World Bank Conference on Development Economics 1998, 237-268. Washington: The International Bank for Reconstruction and Development.

Lebègue, Daniel et al. 2005. Révision du Taux d'Actualisation des Investissements Publics-Rapport du groupe d'experts présidé par Daniel Lebègue. Paris: Commissariat Général au Plan.

Marty, Frédéric, Arnaud Voisin, and Sylvie Trosa. 2006. Les Partenariats Public-Privé. Paris: La Découverte.

Marty, Frédéric and Arnaud Voisin. 2007. "Finances publiques et financements privés: quel nouvel équilibre pour les investissements des Etats ?" Politique et Management Public. 25 (3): 19-37.

QUINET, E. 2006. Transport Cost Benefit Analysis in France: Recent Changes, Progress and Shortcomings, Working Paper no. 22/2006, Dipartimento di Scienze Economiche, Aziendali e Statistiche - Università degli Studi di Milano, Milano 10/2006.

Rosen, Harvey S. 2005. Public Finance. Seventh Edition. New York: McGraw-Hill.

Ruggeri, Giuseppe. 1999. "The Marginal Cost of Public Funds in Closed and Small Open Economies." Fiscal Studies. 20 (1): 41-60.

Snow, Arthur and Warren, Ronald S. Jr. 1996. "The Marginal Welfare Cost of Public Funds: Theory and Estimates." Journal of Public Economics. 61: 289-305.

Spackman, Michael. 2007. "Social Discount Rates for the European Union: an Overview." In Cost-Benefit Analysis and Incentives in Evaluation, edited by Massimo Florio, Northampton: Edward Elgar.

Stuart, Charles E. 1984. "Welfare Cost Per Dollar of Additional Tax Revenue in the United States." American Economic Review. 74: 352-362.

Transport Scotland. 2009. Scottish Transport Analysis Guide, section 12.7: Headline indicators in STAG.

Trosa, Sylvie. 2007. "Le public et le privé: la révision des missions débouche-t-elle sur la sous-traitance ? De l'essence à l'existence." Politique et Management Public. 25 (3): 1-18.

Turno, Roberto. 2010. "Corte dei Conti: la corruzione dilaga." In Il Sole 24 Ore, Issue of February the 18th: 6. Vaquin, M. 1974. "Politique économique et rôle économique de l'État-Commissariat Général du Plan: Calcul économique et planification [Compte Rendu].” Revue économique. 25 (5): 856-859. 